\title{
As perífrases formadas pelo verbo ir + infinitivo na história da língua portuguesa
}

\section{The Periphrasis Formed by the Verb ir + Infinitive in the History of the Portuguese language}

JAn Hricsina [Jan.hricsina@ff.cuni.cz]

Univerzita Karlova, República Checa

\section{RESUMO}

O artigo ocupa-se da análise diacrónica das perífrases foi fazer, ia fazer e vai fazer na língua portuguesa. O objetivo principal do texto é analisar as funções temporais e aspetuais das perífrases em questão no Português Antigo e comparar a sua frequência e o seu emprego na evolução da língua portuguesa. A pesquisa baseia-se no corpus linguístico www.corpusdoportugues.org.

\section{Palavras-chave}

Língua portuguesa; linguística diacrónica; linguística corporal; linguística funcional; perífrases portuguesas foi fazer, ia fazer e vai fazer

\section{Abstract}

The paper focuses on the diachronic analysis of the periphrases foi fazer, ia fazer and vai fazer in the Portuguese language. The principal objective of this study is to analyze the temporal and aspectual functions of these periphrases in Old Portuguese, to compare its frequency and its use in the evolution of the Portuguese language. The research is based on the linguistic corpus www.corpusdoportugues.org.

\section{KEYWORDS}

Portuguese language; diachronic linguistics; corporal linguistics; functional linguistics; Portuguese periphrases foi fazer, ia fazer and vai fazer

RECEBIDO 2018-10-30; ACEITE 2019-02-04

Este artigo teve o apoio do projeto da Universidade Carolina Progres 4, A Língua nas mudanças de tempo, espaço e cultura. 


\section{Introdução}

Um fenómeno comum a várias línguas europeias contemporâneas é a existência da perífrase formada por um verbo de movimento (ir ou vir) e infinitivo. Esta construção analítica serve para exprimir processos posteriores ao momento da fala ${ }^{1}$, ou seja, ações futuras, e tende a substituir, assim, o paradigma do tempo futuro sintético. Esta tendência pode ser observada por exemplo nas línguas germânicas. Enquanto que nestas perífrases as línguas germânicas setentrionais preferem o verbo vir (em Norueguês - komme til å + infinitivo; em Sueco - komma att + infinitivo), as línguas germânicas ocidentais selecionam o verbo ir (em Inglês - to be going to + infinitivo; em Neerlandês - gaan + infinitivo). A mesma tendência manifesta-se também nas línguas românicas contemporâneas. Em Português, Francês e Espanhol, a perífrase formada pelo verbo ir (em Francês aller) no tempo presente e infinitivo vai perdendo a sua função original, ou seja, a de exprimir os processos futuros imediatos, ganhando um novo sema temporal, isto é, a expressão das ações futuras. Além disso, esta perífrase tem também outras variantes formadas pelo verbo ir no pretérito imperfeito ou pretérito perfeito simples. As construções com o imperfeito mantêm sempre o significado de posterioridade relativamente ao ponto de referência ${ }^{2}$ situado no passado (Il a dit que Jean allait venir. ${ }^{3}$.

O objetivo do presente artigo é analisar este tipo de perífrases na evolução do Português Europeu, nomeadamente a sua frequência e os seus significados temporais ou aspetuais. A análise será feita num corpus linguístico que permite realizar pesquisas diacrónicas: $w w w . c o r p u s d o p o r t u g u e s . o r g^{4}$.

\section{Perífrases ir + infinitivo no Português Contemporâneo}

Neste artigo vamos ocupar-nos de três perífrases formadas pelo verbo ir e infinitivo. São as construções vai fazer, ia fazer e foi fazer ${ }^{5}$. Seguidamente vamos explicar o seu emprego e significados.

\subsection{Perífrase vai fazer}

Esta perífrase é formada pelo verbo semi-auxiliar ${ }^{6}$ ir, que está no presente do indicativo, e pelo infinitivo.

1 O momento da fala representa o segmento temporal em que uma frase é proferida (cf. Mateus 2003: 131).

2 O ponto de referência é representado por um ponto intermédio a partir do qual se pode localizar temporalmente o processo descrito (cf. Mateus 2003: 131).

3 Caso não seja indicada a fonte, os exemplos são do autor.

4 O corpus elaborado por Mark Davies (BYU) e Michael J. Ferreira (Georgetown University) contém mais de 45 milhões de palavras nos textos provenientes dos séculos XIII-XX escritos em ambas as variantes principais do Português, respetivamente no Português Europeu e no do Brasil.

5 Além destas perífrases existem também as construções formadas pelo futuro e condicional simples do verbo ir e infinitivo (irá fazer e iria fazer).

6 O verbo ir deve ser considerado semi-auxiliar devido ao facto de poder conservar o seu próprio significado lexical (deslocar-se de um lugar a outro) em certos contextos (Vou ver um amigo.) (Tláskal 1978: 205). 
No passado esta perífrase exprimia processos futuros imediatos (futuro próximo). Figurava, assim, em oposição ao P-farei ${ }^{7}$ que exprimia ações futuras. Ainda nos anos oitenta, os autores da Nova Gramática do Português Contemporâneo afirmavam que a função desta perífrase era a de exprimir uma ação futura imediata (Cunha-Cintra 1999: 459). Depois, a perífrase vai fazer perdeu o sema de proximidade e começou a exprimir ações futuras. A oposição funcional entre os dois paradigmas foi, assim, neutralizada (Tláskal 1978: 209). Quando tal aconteceu, P-vou fazer começou a substituir P-farei na expressão de futuridade. Parece que atualmente este processo já foi (quase) concluído na língua coloquial e começa a invadir a língua escrita (Oliveira 2012: 125). P-farei permanece, porém, a forma mais frequente na língua formal (Svobodová 2014: 89).

No Português Contemporâneo, existem três paradigmas capazes de exprimir ações futuras: P-farei, P-vou fazer e P-faço. Segundo a semanticista portuguesa Fátima Oliveira, cada um tem o seu próprio significado. P-farei exprime uma ação futura possível que geralmente depende de uma condição. P-vou fazer denota um acontecimento futuro que se realizará segundo um plano delineado do locutor. O acontecimento apenas não se efetuará no caso de mudança de estado de coisas, independente do locutor. P-faço exprime uma ação futura cuja realização é considerada como certa. Este paradigma permite a leitura do futuro quando está devidamente contextualizado, por exemplo com advérbios de tempo como amanhã, na próxima semana etc. Segundo a mesma autora, P-vou fazer é a forma mais frequente na língua falada (Oliveira 1985: 357, cf. também Chergova 2009: 204).

\subsection{Perífrase ia fazer}

Esta perífrase é formada pelo verbo semi-auxiliar ir que está no pretérito imperfeito e pelo infinitivo.

P-ia fazer tem dois significados principais. O primeiro é temporal e realiza-se quando a perífrase figura na oração subordinada. Neste caso, denota um processo posterior ao ponto de referência situado no passado (O José disse-nos que ia preparar o jantar.) (Raposo 2013: 1263).

O segundo significado desta perífrase é aspetual, ou melhor, pertence à categoria do caráter da ação verbal ${ }^{8}$. Tal acontece quando figura em frases simples. Neste contexto, pode exprimir uma ação planeada pelo locutor que acabou por não ser realizada. Tem, assim, o caráter dispositivo. Segundo a lusitanista checa Jaroslava Jindrová, este significado não é muito frequente e a sua interpretação é muitas vezes ambígua. Em muitos casos que a autora encontrou, pode ter duas leituras: temporal ou aspetual, ex. Era belo, jovem, brilhante, ia entrar na École Normale de Saint-Cloud. (Jindrová 2016: 41-42). Ao lado desta perífrase coexiste outra construção que tem

7 A abreviatura P significa o paradigma. Por este termo entendemos o conjunto de todas as formas gramaticais dum verbo que têm o mesmo valor modotemporal.

8 Na linguística eslava, costuma distinguir-se entre a categoria do aspeto e a do caráter da ação verbal (Aktionsart). Na tradição eslava, a categoria do aspeto está baseada na oposição entre dois tipos do processo verbal. O primeiro tipo de processo é caraterizado como uma ação complexa ou concluída (perfetivo) e outro tipo de processo como uma ação que ainda está em curso e não foi concluída (imperfetivo). Esta qualidade não está incluída no próprio processo. Depende do ponto de vista do locutor. A segunda categoria considera vários tipos do caráter do processo - qualitativos ou quantitativos como são por exemplo iteratividade, habitualidade, duratividade, frequentatividade etc. À diferença da categoria do aspeto, estas qualidades estão presentes no próprio processo. 
o mesmo significado: ia a fazer. À diferença do P-ia fazer, esta perífrase pode ter apenas a leitura aspetual. Segundo Jaroslava Jindrová esta perífrase é culta, aparecendo nomeadamente nos textos escritos na primeira metade do século XX (e mais antigos), ex. A mestra, que já apanhara os livros e ia a sair, deteve-se, voltou-se. (Jindrová 2016: 41).

\subsection{Perífrase foi fazer}

No conjunto das perífrases que decidimos analisar neste texto, esta é uma construção muito específica. Aparece tipicamente nas frases com uma expressão de lugar direcional. Esta expressão pode ser explícita ou implícita. Veja-se o exemplo seguinte: O Pedro foi ver o futebol (ao Porto). A frase pode ser parafraseada da seguinte maneira: O Pedro foi ao Porto para ver o futebol. Nesta estrutura devemos procurar muito provavelmente a origem da construção foi fazer (Raposo 2013: 1264-1265). Visto que esta perífrase não exprime nenhum valor aspetual ou temporal específico, o verbo ir deve ser considerado como verbo pleno e não semi-auxiliar. Para o linguista português Henrique Barroso, a construção foi fazer é um equivalente expressivo do pretérito perfeito simples $\mathrm{fez}$ e por isso pertence à linguagem coloquial (Barroso 1994: 150).

\section{Perífrases ir + infinitivo no Português Antigo}

As informações sobre as perífrases formadas pelo verbo ir e infinitivo que encontramos em várias gramáticas históricas da língua portuguesa ou em artigos que tratam desta questão, são pouquíssimas. O lusitanista austríaco Joseph Huber afirma que o pretérito perfeito simples é muitas vezes expresso pela perífrase foi fazer (Huber 2006: 248). A linguista diacrónica brasileira Rosa Virgínia Mattos e Silva encontra estas perífrases já no Português Arcaico, explicando que são usadas para a expressão de uma intenção a realizar-se. Vejam-se os exemplos dela: Van demandar outro lugar. Ia tomar o pan. Foi demandar muit'agĩia. (Mattos e Silva 2008: 444). O especialista na sintaxe do Português Arcaico Epiphanio da Silva Dias cita os exemplos da perífrase vou (a) fazer provenientes dos séculos XVI-XIX. Nestes exemplos, o P-vou fazer exprime sempre uma ação futura imediata. Veja-se uma destas frases: Telmo vai a sahir. (Dias 1933: 247).

Apesar de as informações sobre as perífrases em questão serem escassas, confirmam uma hipótese sugerida pelo romanista checo Bohumil Zavadil. Ele supõe que a perífrase espanhola voy a hablar tinha originalmente o valor dispositivo (exprimia uma intenção do locutor a realizar uma ação). No uso moderno, a construção foi gramaticalizada e adquiriu o valor temporal. Porém, a perífrase não perdeu totalmente a capacidade de exprimir o significado dispositivo (Zavadil-Čermák 2010: 278). Supomos que a perífrase portuguesa teve a mesma evolução. 


\section{Métodos de análise}

Para analisar a frequência e o emprego das perífrases formadas pelo verbo ir e infinitivo na evolução da língua portuguesa, aproveitámos o corpus linguístico disponível em www.corpusdoportugues.org que permite fazer pesquisas diacrónicas. Procurámos todas as ocorrências dos sintagmas, compostas pela terceira pessoa do singular do verbo ir nos respetivos tempos e pelo infinitivo (foi_vr*; ia _vr; vai _vr) entre os séculos XIII e XX ${ }^{9}$. De todas as ocorrências encontradas no corpus analisámos 100 casos de cada tipo de perífrase para cada século, sempre que tal número de exemplos esteve à disposição. A seleção dos casos analisados foi aleatória.

\section{Análise in corpora}

\subsection{Século XIII}

Analisando os dados do subcorpus do Português do século XIII, encontrámos 218 ocorrências da perífrase foi fazer na totalidade ${ }^{10}$. Em 100 casos analisados, a perífrase em questão tem duas leituras. Na maioria dos exemplos (84 ocorrências), funciona como uma paráfrase do pretérito perfeito simples (Huber 2006: 248). Vejam-se os exemplos 1 e 2.

(1) Poren quero retraer un miragre que oý, ond' averedes prazer oyndo-o outrossi, per que podedes saber o gran ben, com' aprendi, que a Virgen foi fazer a un bon religioso. (Cantigas de Santa Maria 1)

(2) E o miragre foy assy: Hûa moller morava y que seus fillos, com'aprendi, en pouco tenpo foi perder. (Cantigas de Santa Maria 2)

Nos restantes 16 casos, a perífrase representa uma estrutura composta pelo verbo de movimento ir (no seu sentido original) e pelo infinitivo. Denota, assim, um movimento (já iniciado) orientado a um fim. Este significado é documentado pela presença frequente da preposição $a$ antes do complemento adverbial de lugar (veja-se o exemplo 3).

(3) Afonso X O que da guerra levou cavaleiros e a sa terra foi guardar dinheiros, nom vem al maio. (Cantigas de Escárnio e Maldizer)

Em 8 casos, a perífrase apareceu com o infinitivo ver. O sentido desta construção aproxima-se do significado do verbo visitar (ex. 4).

(4) E depois, quando da terra sayu e que foi veer o Papa que enton era, foi tan mal adoecer que o teve-

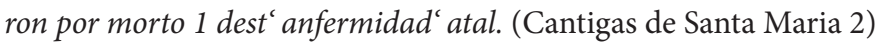

No que diz respeito à perífrase ia fazer, no subcorpus do século XIII registámos apenas 4 casos. Em todos os exemplos, a construção analisada exprime uma ação orientada a um fim, ou seja, o verbo ir figura nela com o seu próprio sentido (verbo de movimento) (ex. 5).

$9 \quad$ A análise in corpora foi feita em agosto e setembro de 2017.

10 No corpus, nesta perífrase apareceu o verbo ir na forma foi em 210 casos e na forma foy em apenas 8 casos. 
(5) E dizend' a grandes vozes: «Sennor, Santa Maria, nenbre-t' o amor que ti avia aqueste pecador que en gëollos t' ia saudar. (Cantigas de Santa Maria 3)

A última perífrase vai fazer foi encontrada em 12 casos. Da análise de todas as ocorrências resulta que esta construção exprime sempre uma ação orientada a um fim (com o verbo ir no seu próprio sentido) (ex. 6).

(6) E cada que el vem a Santarém, sempre aló vai fazer romaria; (Cantigas de Escárnio e Maldizer)

\subsection{Século XIV}

No subcorpus do Português do século XIV, registámos 245 ocorrências da perífrase foi fazer na totalidade ${ }^{11}$. Analisando 100 casos desta construção, concluímos que, em 92 exemplos, a perífrase em questão serve de paráfrase do pretérito perfeito simples ( $f e z)$ (vejam-se os exemplos $7^{12}$ e 8).

(7) Como el rei dom Afomso foi fazer mal aos mouros ë terra de Tolledo e esto per cõsselho d'algûûs mouros da cidade de Tolledo Andados. (Crónica Geral de Espanha de 1344)

(8) De cõmo Éytor falou cõ sseu padre Depoys que Éytor foy armado et caualgou en seu caualo Galatea, cõmo uos ja cõtey, foy falar cõ el rrey, seu padre. (Cronica Troyana)

Em 8 casos, a perífrase denota uma ação iniciada e orientada a um fim e o verbo ir funciona, assim, como verbo de movimento (ex. 9).

(9) E entrou ëna cidade em hûu sabbado, \#VIII dias andados de Dezembro, e foi fazer sua oraçom aaquella igreja onde jazia Sancto Isidoro e os outros corpos sanctos que elle hy trouxera, dizendo a Deus em esta guisa: (Crónica Geral de Espanha de 1344)

No que diz respeito à perífrase ia fazer, não encontrámos nenhuma ocorrência ${ }^{13}$. A perífrase vai fazer não foi encontrada no subcorpus do Português do século XIV.

11 Na perífrase analisada, encontrámos a forma foi em 32 casos e a forma foy em 213 ocorrências. A proporção entre as formas da 3. pessoa do singular do pretérito perfeito simples do verbo ir revelou-se oposta em comparação aos resultados obtidos na análise do século XIII.

12 No exemplo 7, a construção foi fazer não pode ser interpretada como uma estrutura composta pelo verbo de movi-

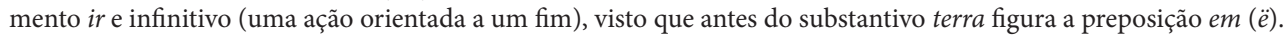

13 No subcorpus do século XIV, o sintagma ia fazer apareceu oito vezes, mas em todas as ocorrências a palavra ia representava o advérbio já. 


\subsection{Século XV}

No subcorpus do Português do século XV, encontrámos, no total, 203 ocorrências da perífrase foi fazer ${ }^{14}$. No conjunto de 100 casos analisados desta perífrase, registámos 72 exemplos em que a perífrase serviu de paráfrase do pretérito perfeito simples (ex. 10).

(10) Entom lhi foi dar ûa tam grande espadada que lhi deitou o elmo da cabeça em terra. (A Demanda do Santo Graal)

Em 28 casos, esta perífrase funcionou como uma união livre do verbo ir e infinitivo (ex. 11). Porém, em algumas ocorrências registámos estruturas semi-fixas, como por exemplo foi ver (visitar) ou foi buscar (ex. 12).

(11) Assy que, ho Ifante esteve sobre Tanger trinta e sette dias, nos quaes foi vinte e cinco cercador, $e$ os doze cercado, em que dos Christaaõs morrerom atee quinhentos, de que foram oyto Fidalgos com Joham Rodrigues Coutinho, que ferido foy morrer a Cepta, e dos Mouros morreriam bem quatro mil, como se ja disse. (Rui de Pina, Crónica de D. Duarte)

(12) Assi se partio el-rei do cavaleiro e foi buscar sa companha ataa que a achou. (A Demanda do Santo Graal)

Quanto à perífrase ia fazer, registámos apenas duas ocorrências. Em ambos os casos a construção denota um processo orientado a um fim. Vejam-se os exemplos 13 e 14.

(13) Mas com Ercoles la foi buscar todollos grandes de Grecia, mancebos de sua idade que fossem com elle, porque ia pelejar com homens e não com bestas feras porque era mui lonje de sua terra. (Coronica troiana em linguajem purtuguesa)

(14) E ela cuidava que, pois se ela ia deitar a par dele, que el comprisse seu coraçom. (A Demanda do Santo Graal - cópia do século XV)

A perífrase vai fazer encontra-se representada por apenas 3 ocorrências. A sua função foi sempre a de exprimir uma ação orientada a um fim (ex. 15).

(15) Pollo qual te rogo que tomes quanta parte de meus tisouros quiseres e vai tomar e ganhar a maior honra e empresa do mundo". (Coronica troiana em linguajem purtuguesa)

\subsection{Século XVI}

Analisando a perífrase foi fazer no subcorpus do Português do século XVI, registámos um total de 777 ocorrências ${ }^{15}$. No conjunto de 100 casos observados, registámos 82 exemplos em que esta

14 Registámos 81 casos da perífrase com a forma foi e 122 exemplos com a forma foy.

15 Encontrámos 635 casos da perífrase com a forma foi e 142 exemplos com a forma foy. 
perífrase funcionou como uma paráfrase do pretérito perfeito simples $(f e z)$. Vejam-se os exemplos 16 e 17.

(16) ...e espedido de Moçambique, foi fazer sua aguada em as Ithas de Pemba, onde lhe houveram de enxovalhar ûa pouca de gente; (João de Barros, Décadas da Asia - Década Segunda, Livros $\mathrm{I}-\mathrm{X})$

(17) Vinda a monção, se embarcou Jordão de Freitas, e foi surgir em Talangame, como atrás dissemos. (Diogo do Couto, Quinta década (livros 8-10), vol. 1, Décadas)

Nos restantes 18 casos, o sintagma foi fazer exprimia sempre uma ação orientada a um fim (ex. 18 e 19).

(18) Da qual vinda el-Rei de Melinde foi logo avisado, e o foi receber a um certo lugar onde houveram batalha. (João de Barros, Décadas da Asia - Década Primeira, Livros I-X)

(19) E assim quando desembarcou o foi esperar à praia, sem lhe fazer a ceremónia da entrega das chaves, como era costume em todas as fortalezas... (Diogo do Couto, Quinta década (livros 8-10), vol. 1, Décadas)

Diferentemente da situação registada nos séculos anteriores, observámos um número crescente de casos da perífrase ia fazer. Encontrámos 98 ocorrências na totalidade. Da análise de todos os casos registados resulta que os significados desta perífrase são idênticos aos encontrados na construção foi fazer. Portanto, em alguns casos a perífrase funciona como uma paráfrase do pretérito imperfeito (ex. 20) e em outros denota um processo orientado a um fim (ex. 21 e 22). Em muitos casos é extremamente difícil distinguir estas duas leituras e, por isso, não fizemos estatísticas das ocorrências. Não registámos nenhum caso em que esta perífrase exprimisse o sentido dispositivo ou uma ação posterior a outra ação pretérita. Do ponto de vista sintático, constata-se que a construção ia fazer nunca figura em frase simples.

(20) Porque com aquele primeiro ímpeto da entrada da porta, os que foram com ele, e outros que entraram per outra parte, começaram de se espalhar de maneira, que não enxergavam entre tanta multidão de mouros; e feitos em um corpo, deu outro Santiago onde se fazia ûa maneira de rua larga, que ia dar na outra fortaleza. (João de Barros, Décadas da Asia - Década Terceira, Livros I-X)

(21) E entre os mouros e gente da terra era tamanha, que a gente pobre se achava morta pelas ruas, $e$ os mais deles, se não morriam à fome, eram mortos per as tigres do mato, onde esta pobre gente ia buscar algûa fructa agreste e talos de ervas pera comer, a qual necessidade também Pate Quetir padecia em sua povoação. (João de Barros, Décadas da Asia - Década Segunda, Livros I-X)

(22) O qual, enquanto esteve naquela Ilha Maçuá, sempre ia ouvir missa à mesquita da povoação, à qual mandou poer nome Santa Maria da Conceição; (João de Barros, Décadas da Asia - Década Terceira, Livros I-X)

No que diz respeito à perífrase vai fazer, registámos 96 ocorrências dela. Analisando estes casos, constatámos que é também muito difícil interpretá-los com exatidão. Por isso, não fizemos 
estatística exata. De qualquer modo, a análise de todas as ocorrências revelou que esta perífrase denota um leque de vários significados. Em algumas ocorrências, a construção exprimia um processo orientado a um fim (como nas outras perífrases) (ex. 23). Neste tipo de casos, a construção encontra-se por vezes no modo imperativo (ex. 24).

(23) ...porque como cada hum trabalha de enganar por todas as vias que pode ao outro, nenhum se fia das balãças e pesos do outro, e todo ho que vai comprar a praça leva balança e prata quebrada... (Enformação das cousas da China)

(24) Se de tua porfia não desistes, vai repastar teu gado a outra parte; (Luís de Camões, Obras) Em outro tipo de exemplos, a perífrase funciona como uma paráfrase do presente do indicativo (faz) (ex. 25 e 26).

(25) E caminhando deste fim do Nilo pela parte do Ocidente, que descrevemos, fazendo ûa maneira de arco não mui curvo, que vai fenecer contra o Sul, chega ao reino Adeá, que é a mais austral terra que ele tem; nas serras do qual nasce o rio Obi, a que Ptolomeu chama Raptus, que vai sair ao Oceano, na povoação Quilmance, junto de Melinde. (João de Barros, Décadas da AsiaDécada Terceira, Livros I-X)

(26) Fogem as vacas para a agoa porque a mosca as vai seguir eu soo, triste em minha magoa, nam tenho onde fugir. (Bernardim Ribeiro, Menina e moça)

Acrescente-se que registámos também um número reduzido de casos em que a perífrase analisada exprimia uma ação posterior ao momento da fala, ou seja, o futuro ou futuro próximo (ex. 27 e 28). No entanto, dada a escassez de exemplos, achamos que, no século XVI, este emprego estava longe de se encontrar gramaticalizado. Também esta perífrase não figura em frases simples (com exceção do modo imperativo).

(27) Mas ele de tençoeiro sem ganhar nisso ceitil vai dar chuvas em Janeiro e geadas em Abril e calmas em Fevereiro e névoas no mês de Maio e meado Julho pedra eu trabalho atás que caio pardeos ele que é meu aio cada vez mais me desmedra. (Gil Vicente, Obra completa)

(28) A dos Fonccenxum: estes adoram o Sol, e dizem, que depois que um morre, vai viver lá outra vida em outro Mundo. (Diogo do Couto, Quinta década (livros 8-10), vol. 1, Décadas)

\subsection{Século XVII}

A pesquisa da perífrase foi fazer no subcorpus do Português do século XVII mostrou um total de 219 ocorrências ${ }^{16}$. Analisando 100 casos, descobrimos que em 86 exemplos a perífrase funcionava como uma paráfrase do pretérito perfeito simples. Vejam-se os exemplos 29 e 30.

(29) Pela última de V. M. de 24 de Janeiro, vejo que V. M. foi fazer uma novena ao Campo Grande em louvor dos Santos Reis, e queira Deus que a boa estrela destes peregrinos coroados me leve em salvo a Lisboa, assim como os levou a eles a Belém. (José da Cunha Brochado, Cartas) 
(30) Deu logo velas pera Maçuá, que era o fim da viagem, e foi ancorar no porto por fim de março. (Frei Luís de Sousa, Anais de D. João III)

Em 14 casos, a construção foi fazer exprimia uma ação orientada a um fim, ou seja, representava uma união livre do verbo ir e infinitivo (ex. 31 e 32).

(31) O mesmo Saul, que desterrou a Pitonisa, a foi buscar e se serviu de sua má arte; (António Vieira, Historia do Futuro)

(32) Em Santa Susana parou o Arcebispo a jantar e foi dormir a Xamon, caminhando sempre costa abaixo, mas já a cavalo, e serras menos agras. (Luis de Sousa, A vida de Frei Bertolameu dos Mártires)

No que diz respeito à pesquisa da perífrase ia fazer, no subcorpus do Português do século XVII encontrámos apenas 15 casos. Na maioria dos exemplos, a construção analisada funcionava como uma paráfrase do pretérito imperfeito (ex. 33) ou denotava uma ação orientada a um fim (ex. 34).

(33) Estes poucos bárbaros assistem nos matos dos ilhéus, últimos confins desta Diocese, de onde o arcebispo começou a sua visita, que acabou gloriosamente em uma residência nossa nas entradas do sertão, onde ia tomar os exercícios de Santo Inácio; (Padre António Vieira, Cartas)

(34) ...e tôdas estas, e ainda um exórdio de sentença que hei por escusado, se vêem em uma carta que há pouco li, que um Rei de Portugal antigo escreveu ao de França, encomendando-lhe um fidalgo que ia estudar a Paris; (Francisco Rodrigues Lobo, Côrte na Aldeia e Noites de Inverno)

Registámos também um caso em que esta perífrase tinha um significado dispositivo ou denotava uma ação posterior a outro processo pretérito. Veja-se o exemplo 35.

(35) De maneira que nêle está a condenação ou a justificação, a morte ou a vida de quem o possui ou deseja; para o que eu acho extremada aquela história que toca Ausónio poeta em um seu epigrama, e é que um homem, desesperado com uma paixão que teve, se ia enforcar em um lugar secreto, levando consigo o baraço em que havia de deixar a vida. Sucedeu que, com a fôrça que fêz, caindo uma parte da terra naquele lugar se lhe descobriu um tesouro, a cuja vista mudou logo o pensamento: e, levando o que achara, deixou em seu lugar o baraço que trazia. (Francisco Rodrigues Lobo, Côrte na Aldeia e Noites de Inverno)

No subcorpus do Português do século XVII, registámos 54 ocorrências da perífrase vai fazer. Esta construção exprimia alguns significados. Os casos mais frequentes encontravam-se representados pelos exemplos em que exprimia seja o tempo presente (ex. 36) seja uma ação orientada a um fim (ex. 37).

(36) Lava-lhe os muros o rio Adige, chamado Athesis dos Latinos, que corre contra Itália, crecido já de águas, e navegável, e vai entrar no Mar Adriático. (Luis de Sousa, A vida de Frei Bertolameu dos Mártires)

(37) Quem abrolhos semea, espinhos colhe. Quem çea, \& se vai deitar, má noite há de passar. (Antonio Delicado, Adagios) 
Registámos também alguns casos em que esta perífrase exprimia uma ação posterior ao momento da fala ou tinha um sentido dispositivo. Vejam-se os exemplos 38 e 39.

(38) Holanda dizem que aparelha nova e mais poderosa armada, e que França se tem declarado por sua parte; que os príncipes de Alemanha se armam, sem se saber o fim; que em Polónia começam grandes revoluções, e que se temem em Europa mais universais guerras que nunca; que Carracena, feito grande, vai governar Nápoles; e que a conquista de Potugal se torna a entregar a D. João de Áustria. (Padre António Vieira, Cartas)

(39) Também dizem que há-de chegar a essa corte, onde foi bem aceito, e que vai estabelecer certos intentos em ordem ao futuro conclave. (Padre António Vieira, Cartas)

\subsection{Século XVIII}

No subcorpus do Português do século XVIII, registámos 105 ocorrências da perífrase foi fazer na totalidade ${ }^{17}$. Analisando 100 casos selecionados, constatámos que em 80 ocorrências a perífrase em questão funcionava como uma paráfrase do pretérito perfeito simples (ex. 40) e nos restantes 20 casos exprimia uma ação orientada a um fim (ex. 41).

(40) José Lopes desapareceu daqui pelo Santo António, depois de ter vivido por um modo que lhe doeria bem a seu pai quando lá lhe chegasse a notícia; passado pouco tempo se soube que foi dar consigo em Nápoles, e começava lá com a mesma vida. (Antonio da Costa, Cartas do Abade António da Costa)

(41) Meu amigo e Senhor: Pela última de Vossa Mercê de 24 de Janeiro, vejo que Vossa Mercêfoi fazer uma novena ao Campo Grande em louvor do Santos Reis, e queira Deus que a boa estrêla destes peregrinos coroados me levem salvo a Lisboa, assim como os levou a eles a Belém. (J. Cunha Brochado, Cartas)

A perífrase ia fazer foi representada por apenas 13 ocorrências. As suas funções são idênticas às observadas nos exemplos do século anterior, ou seja, paráfrase do pretérito imperfeito (ex. 42) e expressão duma ação orientada a um fim (ex. 43).

(42) De Veneza não tenho que diga a Vossa Mercê senão o que já fiz noutra; mas como é de crer que não lhe chegasse à mão, porque o levou um capitão de um navio dinamarquês que ia visitar todos os portos do Mediterrâneo antes de aportar a Lisboa... (Antonio da Costa, Cartas do Abade António da Costa)

(43) Sobreveio a estes miseráveis nova desgraça, para mais lhes agravar as jornadas, porquanto a canoa, que ia buscar provimento à i!ha, com a força de uma tormenta se foi a pique e afogaram-se quantos nela navegavam. (Manuel Consciência, Academia universal)

Registámos também dois casos da perífrase ia fazer que exprimia um processo posterior a uma ação pretérita. Veja-se o exemplo 44.

17 Encontrámos 54 casos da perífrase com a forma foi e 51 ocorrências com a forma foy. 
(44) Disse-lhe o confessor que desta forma se ia meter directamente no Inferno. (Cavaleiro de Oliveira, Cartas)

No que diz respeito à perífrase vai fazer, encontrámos 42 ocorrências. Os resultados da pesquisa são também muito semelhantes aos observados para o século anterior. A construção analisada exprime ou o tempo presente (paráfrase do tempo presente) (ex. 45) ou uma ação orientada a um fim (ex. 46 e 47).

(45) Desde o riacho, que vai acabar em outro grande rio Vasconcel. (Rafael Bluteau, Vocabulario portuguez, e latino... A1)

(46) Daqui podeis observar um pequeno bosque, onde Natan vai passear pela manhã ficando todos os dias ali algumas horas. (Cavaleiro de Oliveira, Cartas)

(47) Aos teatros concorre todo o mundo com a ideia de que só vai divertir-se e recrear-se. (Correia Garcao, Obras Completas)

O contexto em que figuram algumas ocorrências desta perífrase aponta também para o significado do futuro. Veja-se o exemplo 48.

(48) Se morrem ou vivem é só por sua conta, nem dão que fazer à liberalidade, nem à compaixão. Esse Parlamento vai estabelecer um fixo equilíbrio na Europa para conservar uma paz segura, mas, se as coisas da Alemanha, pela separação de Baviera, correrem como até agora, temo que percam o trabalho dêste santo e glorioso projecto. (J. Cunha Brochado, Cartas)

Em alguns casos, não é evidente se esta perífrase exprime uma ação futura ou um processo orientado a um fim (união livre do verbo ir e infinitivo). Veja-se o exemplo 49.

(49) ...porque o pobre, que só tem o seu braço, enquanto pode ganhar para a sua sustentaçao à sombra e sentado, ou vendendo contrabandos ou fazendo trapaças e promovendo a chicana do fôro, ou trepado na traseira de uma sege, não vai trabalhar de pé ou curvado ao sol è chuva, exposto a todas as inclemências do tempo. (J. J. da Cunha Azeredo Coutinho, Obras econômicas)

\subsection{Século XIX}

No que diz respeito à pesquisa da perífrase foi fazer, no subcorpus do Português do século XIX, registámos um total de 1313 ocorrências dela ${ }^{18}$. Analisando 100 casos selecionados, encontrámos 69 exemplos em que esta perífrase funcionava como uma paráfrase do pretérito perfeito simples (fez). Repare-se nos exemplos 50 e 51.

18 No subcorpus do século XIX, encontrámos exclusivamente as perífrases com a forma foi. O conjunto de todas as ocorrências das perífrases analisadas (foi fazer, ia fazer e vai fazer) pertencem a ambas as variantes do Português, respetivamente ao Português Europeu e ao Português do Brasil. Por motivos técnicos, não foi possível separar os dois tipos de exemplos neste subcorpus. 
(50) A rápida cena que tinha suscitado aqueles estrondosos aplausos repetiu-se então com rapidez ainda maior. Segundo mastim foi cair semimorto na arena; mas os mugidos do touro haviam-se convertido em urros de desesperação. (Alexandre Herculano, O Bobo)

(51) E Vilaça foi encontrar Afonso na livraria, com as janelas cerradas ao lindo sol de inverno, caído para uma poltrona, a face cavada sob os cabelos crescidos e brancos, as mãos magras e ociosas sobre os joelhos.. (Eça de Queirós, Os Maias)

Nos restantes 31 casos, a perífrase foi fazer exprimia uma ação orientada a um fim. É de notar que o significado desta construção dependia do tipo de verbo (no infinitivo). Os verbos como comer, jantar e dormir tinham sempre esta leitura. Vejam-se os exemplos 52 e 53.

(52) Corridas as primeiras curas das feridas, cada um foi dormir descansadamente e ninguém se lembrou de chamar o médico. (Fialho de Almeida, A Ruiva)

(53) Então o Sr. Barrolo hoje não janta - O Sr. Barrolo foi jantar com o Sr. Barão das Marges, na quinta.. São os anos da menina. (Eça de Queirós, A Ilustre Casa de Ramires)

Analisando a perífrase ia fazer, notámos uma mudança radical no comportamento desta construção. Registámos 1343 ocorrências desta perífrase na totalidade. A análise de 100 casos selecionados mostrou que a construção tinha apenas duas funções: primeiro pode exprimir uma ação posterior a outra pretérita (ex. 54 e 55) e segundo pode ter um sentido dispositivo (ex. 56, 57 e 58). Diferentemente do observado para os séculos anteriores, esta perífrase pode figurar em frases simples (ex. 55). Em alguns casos, revelou-se muito difícil distinguir as duas funções e por isso não fizemos estatística.

(54) Senti que era chegada a minha hora, pareceu-me que ia ser expulso daquele Éden de inocência em que tinha vivido. (Almeida Garrett, Viagens na minha terra)

(55) Contou imediatamente a grande desgraça que tinha em casa, uma irmã meio idiota entrevada havia dez anos! Ia fazer sessenta anos. (Eça de Queirós, O Crime do Padre Amaro)

(56) Macário ficou imóvel, deu dois passos no quarto, todo revoltado, e ia sair. - Onde vai, seu estúpido? - gritou-lhe o tio. - Vou-me. - Sente-se ali! (Eça de Queirós, Singularidades de uma rapariga loura)

(57) Aqui hesitou alguns instantes, porque lhe parecia demasiado lisonjeiro o que ia dizer, mas afinal sempre concluiu: - Nem.. nem.. nem o deixo trabalhar a ele. (Júlio Dinis, Uma Família Inglesa)

(58) Luísa sorriu, ia responder - mas viu o sujeito pálido de pêra longa que fitava nela os seus olhos langorosos, com obstinação. Voltou o rosto importunada. O sujeitoafastou-se, retorcendo a ponta da pêra. (Eça de Queirós, O Primo Basílio)

A perífrase vai fazer encontra-se representada por 1372 ocorrências. Do conjunto de 100 casos analisados constata-se que a expressão do futuro próximo é de longe a mais frequente (ex. 59 e 60).

(59) Em todo o caso, creio que cumpri. Ouço que vai ser nomeado cónego. Larguissimamente o merece. (Eça de Queirós, Correspondência de Fradique Mendes) 
(60) Falava-lhe como a uma criancinha pequena, dizia-lhe: "Isso vai passar, amanhã estás boa, vamos passear » (Eça de Queirós, O Primo Basílio)

Em alguns casos, esta perífrase exprimia o imperativo (ex. 61) ou uma exclamação orientada para o futuro (ex. 62 e 63).

(61) Telmo, vai fazer o que te mandei. (Almeida Garrett, Frei Luís de Sousa)

(62) E vós, senhores, recuai para a lomba do cerro, comopara palanque, que vai ser grande a vista! (Eça de Queirós, A Ilustre Casa de Ramires)

(63) Coitada! Não tem má cruz, ir aturar a velha! E depois naturalmente vai dar o seu passeio! Faz ela muito bem! (Eça de Queirós, O Primo Basílio)

A construção vai fazer pode exprimir excecionalmente também uma ação orientada a um fim (significado frequente nos séculos anteriores). Veja-se o exemplo 64.

(64) Além disso Sarah deixa Paris amanhã. Vai descansar dois dias para o campo em casa dos filhos e parte no Domingo para Londres onde vai representar todas as noites até o fim da season, para voltar em setembro a representar todas as noites em Paris, como representa agora. (Ramalho Ortigão, Cartas a Emília)

\subsection{Século XX}

Analisando a perífrase foi fazer no subcorpus do século XX, constatámos que o seu comportamento semântico era diferente do observado para os séculos anteriores. Em 100 casos analisados (de 1204 ocorrências registadas na totalidade ${ }^{19}$ ), esta construção exprimia exclusivamente ações orientadas a um fim (união livre do verbo ir e infinitivo). Repare-se nos exemplos 65 e 66.

(65) Foi trabalhar para o Observatório Lick, na Califórnia, quando este abriu, em 1888. (Edward Emerson Barnard)

(66) Depois de se tornar padre, foi estudar para Paris em 1495. (Desidério Erasmo)

No que diz respeito à análise da perífrase ia fazer, encontrámos 705 ocorrências no subcorpus do Português Europeu. Na maioria dos 100 casos analisados, esta construção denota ações posteriores a outros processos pretéritos (ex. 67, 68 e 69). A perífrase tinha este significado temporal também no caso de figurar em oração principal (ex. 68). Em seguida, encontrámos 5 casos da construção semi-fixa ia ver (visitar) (ex. 70). Apenas excecionalmente apareceram casos em que a perífrase ia fazer podia ter a leitura dispositiva. Veja-se o exemplo 71.

(67) Sabia de antemão que ia ser complicado passar 90 minutos sem sofrer qualquer golo, porque o Benfica tem avançados muito bons, mas a nossa defesa funcionou sempre muito bem. (Nuno Santos, 97Set15) 
(68) Dali em diante o trabalho ia ser menos pesado porque repartia com um maloio o caminho entre a caldeira grande e a bomba. (José Cardoso Pires, Estrada 43)

(69) A Graça disse ao Pedro que ia ficar muito quietinha, ao pé dele, no Hotel porque já não eram horas de ir para parte nenhuma. (Antonio Alçada Baptista, Os nos e os Laços)

(70) Acordava tarde de janela escancarada para vasta planície, dava passeios higiénicos pelos pinhais próximos, ia ver o pôr-do-sol mas, maldita memória, esta última imagem poente ainda me trazia qualquer coisa de marinho! (Rúben Andresen, Páginas)

(71) Angela, sua filha mais velha, completava dezóito anos - „ia entrar na sociedade „, como costumava dizer D. Guiomar, quando se referia ao acontecimento. (João Gaspar Simões, Pantano) A perífrase vai fazer foi representada por 2848 casos no subcorpus do Português Europeu. Em 100 exemplos analisados, esta construção exprimia exclusivamente ações posteriores ao momento da fala, ou seja, futuras. Vejam-se os exemplos 72 e 73.

(72) O que é que o PSD vai fazer, em termos distritais, com vista às próximas autárquicas? (Alvaro Amaro, 96-09-12)

(73) Sei que em Novembro próximo vai sair o vosso primeiro „ single „. (A música „rap“, 97-08-24-4)

\section{Comparação da frequência das perífrases na evolução da língua portuguesa}

Neste pequeno capítulo vamos comparar a frequência das perífrases estudadas no corpus $w w w$. corpusdoportugues.org em cada século ${ }^{20}$. Na tabela e no gráfico seguintes, apresentamos os valores i.p.m. (item por milhão) de cada perífrase $\mathrm{e}^{21}$ em cada século.

\begin{tabular}{|c|c|c|c|c|c|c|c|c|}
\hline & séc. XIII & séc. XIV & séc. XV & séc. XVI & séc. XVII & séc.XVIII & séc. XIX & séc. XX \\
\hline foi fazer & 402,93 & 24,85 & 39,02 & 178,62 & 49,2 & 32,43 & 192,68 & 91,05 \\
\hline ia fazer & 9,07 & 8,54 & 3,87 & 23,77 & 5,81 & 5,94 & 228,83 & 117,65 \\
\hline vai fazer & 25,41 & 0,78 & 1,76 & 23,77 & 16,81 & 19,18 & 206,95 & 535,48 \\
\hline
\end{tabular}

Tabela 1. A frequência relativa das perífrases foi fazer, ia fazer e vai fazer na evolução da língua portuguesa (valores i. p. m.)

Analisando os dados da frequência relativa da perífrase foi fazer, ficamos a saber que esta construção era mais frequente no início do Português Antigo (no século XIII). Nos séculos posteriores, a sua frequência diminuiu consideravelmente com duas exceções nos séculos XVI e XIX.

Da análise da frequência relativa da perífrase ia fazer resulta que é só no século XIX que esta construção começou a ser usada regularmente. Esta mudança tem a ver com o facto de, naquele período, dois significados desta perífrase, ou seja, a expressão dos processos posteriores a outras ações pretéritas e a leitura dispositiva, se terem propagado de uma maneira considerável.

20 Nos séculos XIX e XX, na análise estão incluídas as ocorrências tanto do Português Europeu quanto do Português do Brasil.

21 No que diz respeito à perífrase foi fazer, os valores i. p. m. estão válidos apenas para a perífrase com a forma foi. A perífrase com a forma foy não foi incluída nos resultados. 


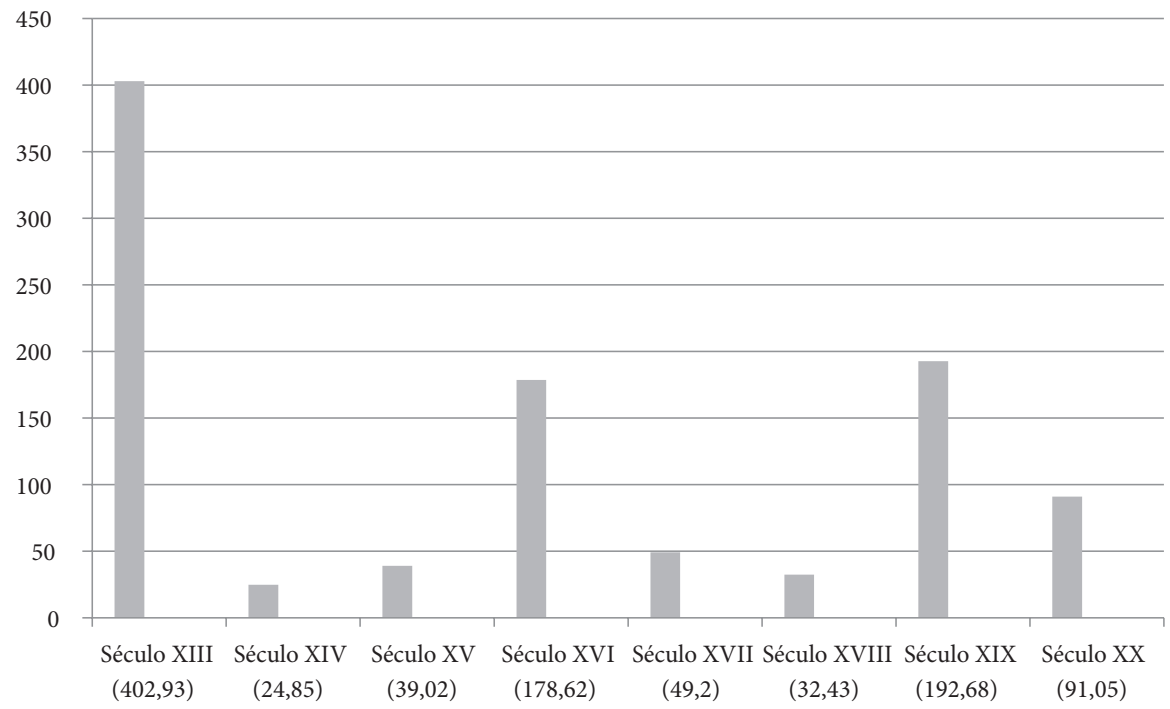

Gráfico 1. A frequência relativa da perífrase foi fazer na evolução da língua portuguesa (valores i. p. m.)

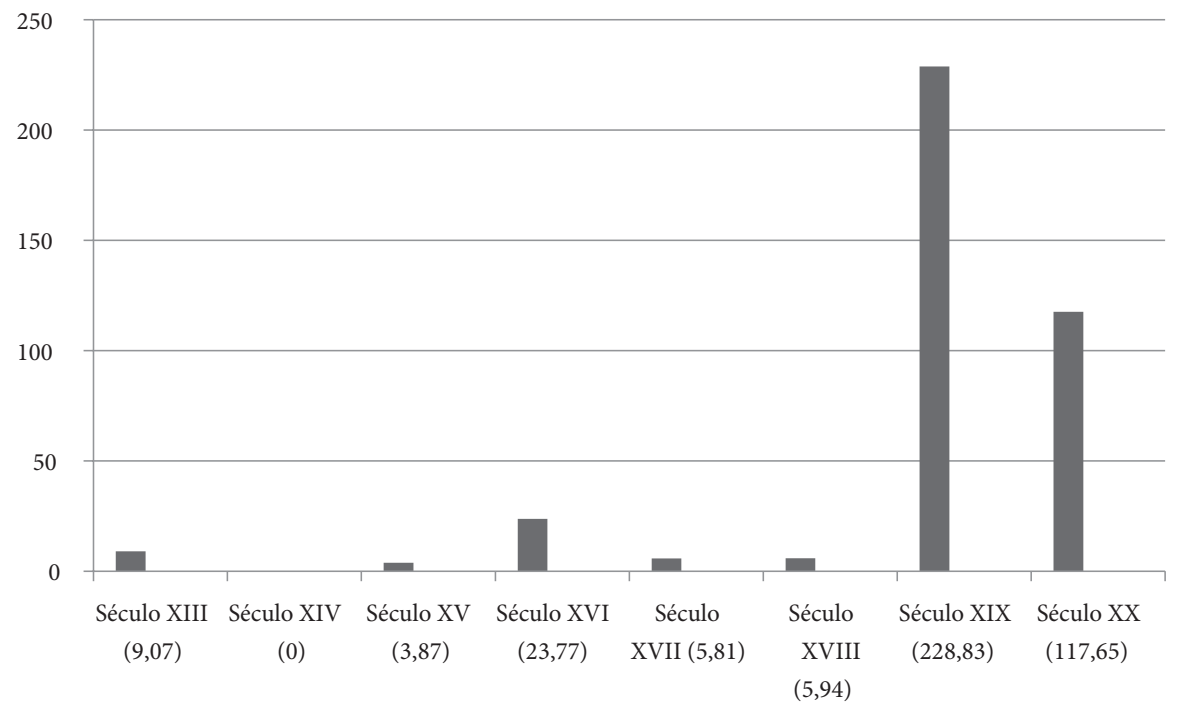

Gráfico 2. A frequência relativa da perífrase ia fazer na evolução da língua portuguesa (valores i. p. m.) 


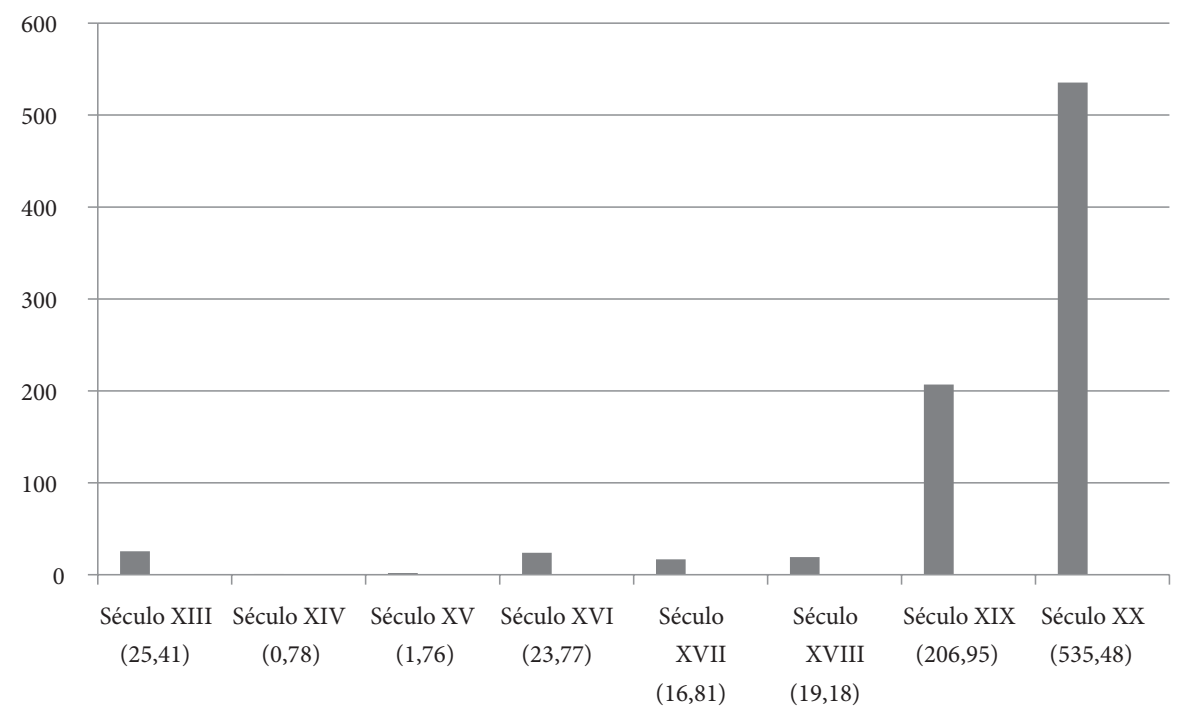

Gráfico 3. A frequência relativa da perífrase vai fazer na evolução da língua portuguesa (valores i. p. m.)

A perífrase vai fazer começou a ser usada regularmente também só no século XIX visto que, naquela época, a expressão do próximo futuro ou futuro se propagou consideravelmente.

\section{Conclusões}

A pesquisa efetuada no corpus www.corpusdoportugues.org mostrou os seguintes resultados. A perífrase foi fazer tinha duas funções (paráfrase do pretérito perfeito simples e expressão de uma ação orientada a um fim) do século XIII até ao século XIX. No século XX deixou de funcionar como uma paráfrase do pretérito perfeito simples. Esta construção era mais frequente no início do Português Antigo (século XIII). Desde aí, a sua frequência diminuiu sensivelmente.

Entre os séculos XIII e XVIII, a perífrase ia fazer funcionava seja como paráfrase do pretérito imperfeito seja denotando processos orientados a um fim. No século XIX, mudou completamente o seu comportamento, começando a denotar ações posteriores a outros processos pretéritos ou ter uma leitura dispositiva. A sua frequência cresceu consideravelmente também no século XIX.

Resultados semelhantes foram obtidos também para a perífrase vai fazer. Do século XIII até ao século XVIII, funcionava como uma paráfrase do presente do indicativo ou denotava processos orientados a um fim. No século XIX, começa a exprimir o futuro próximo e no século XX as ações futuras. A sua frequência subiu também duma maneira considerável nos séculos XIX e XX.

A mudança do comportamento sintático das perífrases ia fazer e vai fazer ocorreu no século XIX. Porém, é preciso apontar para o facto de que a pesquisa foi efetuada no corpus do Português escrito. Sabendo-se que a língua escrita vem refletindo a evolução posteriormente à oralidade, podemos avançar a hipótese de que as duas perífrases começaram a exprimir as novas funções ligeiramente antes do século XIX, provavelmente no século anterior. 


\section{Referências bibliográficas}

Barroso, H. (1994). O Aspecto Verbal Perifrástico em Português Contemporâneo (visão funcional/sincrónica). Porto: Porto Editora.

Chergova, V. (2009). Particularidades do Sistema Verbal Português no Indicativo. Études romanes de Brno, 30 (1), 197-209.

Cunha, C.; \& Cintra, L. $\left(1999^{15}\right)$. Nova Gramática do Português Contemporâneo. Lisboa: João Sá da Costa.

Dias, A. E. da S. (1933²). Syntaxe Historica Portuguesa. Lisboa: Livraria Clássica Editora.

Hendrich, J.; Radina, O.; \& Tláskal, J. (1991). Francouzská mluvnice. Praha: SPN.

Huber, J. (2006²). Gramática do Português Antigo. Lisboa: Fundação Calouste Gulbenkian.

Jindrová, J. (2016). Perifrastické konstrukce v portugalštině. Praha: Karolinum.

Krijtová, O.; \& Červenková, J. (2014). Učebnice nizozemštiny. Praha: Karolinum.

Mateus, M. H. M. (Eds.). (2003). Gramática da língua portuguesa. Lisboa: Caminho.

Mattos e Silva, R. V. (2008). O português Arcaico-Volume I - Léxico e morfologia. Lisboa: Imprensa nacional-casa da moeda.

Mikolášková, L.; Švejdová-Pinkasová, I.; \& Winklerová, K. (2007). Norština nejen pro samouky. Praha: Leda. Nováková Jíchová, E.; Robovská, L.; \& Falkenström, B. (2012). Švédština nejen pro samouky. Praha: Leda.

Oliveira, F. (1985). O futuro em português, alguns aspectos temporais e/ou modais. Actas do $1^{\circ}$ encontro da Associação Portuguesa de Linguística. 353-373.

Oliveira, J. M. de. (2012). A Expressão do futuro verbal na escrita jornalística baiana. Revista Linguística / Revista do Programa de Pós-Graduação em Linguística da Universidade Federal do Rio de Janeiro, 8 (1), 125-137. <http://www.letras.ufrj.br/poslinguistica/revistalinguistica/wp-content/uploads/2012/06/revista-linguistica-v8-n1-a-expressao-do-futuro-verbal1.pdf>

Raposo, E. P. (Eds.). (2013). Gramática do Português - Volume II. Lisboa: Fundação Calouste Gulbenkian. Svobodová, I. (2014). Morfologie současného portugalského jazyka II. Sloveso. Brno: Masarykova univerzita. Tláskal, J. (1978). Remarques sur le futur en portugais contemporain. Philologica pragensia, 21(4), 204-213. Zavadil, B.; \& Čermák, P. (2010). Mluvnice současné španělštiny. Praha: Karolinum. 